\title{
Household Management of Pesticides and Chemical Contaminants in Fruit and Vegetables
}

\author{
Rostislav Yu. Smirnov*a, Shubhra Pande ${ }^{a}$, \\ Oxana A. Kolenchukova ${ }^{a, b}$ and Valentina A. Kratasyuk ${ }^{a, c}$ \\ ${ }^{a}$ Siberian Federal University \\ 79 Svobodny, Krasnoyarsk, 660041, Russia \\ ${ }^{b}$ Science-Research Institute for Medical Problems in the North \\ $3 g$ Partizan Zheleznyak Str., Krasnoyarsk, 660022, Russia \\ ${ }^{c}$ Institute of Biophysics SB RAS \\ Federal Research Center \\ "Krasnoyarsk Science Center SB RAS" \\ 50/50 Akademgorodok, Krasnoyarsk, 660036, Russia
} Received 10.03.2017, received in revised form 17.05.2017, accepted 20.05.2017

There is an indiscriminate use of pesticides, artificial ripening agents, waxes, dyes, etc. on fruits and vegetables and unknowingly the entire population consumes them. Pesticides are extremely mobile, biostable and contaminate the entire ecosystems. Their potential hazard to human health is very well investigated, and, as a result, many pesticides have been banned in several countries. Artificial ripening agents cause immature ripening and contamination of the fruit causing cancers, allergies, hormonal imbalances, etc. Further, waxes, dyes, shiners are added to impart deceptive appearance to fruit and vegetables, so as to earn profit at the cost of human health. Awareness about simple food processing and careful selection techniques can effectively reduce the risks of adverse health effects.

Keywords: pesticides, artificial ripening agents, food processing, contamination.

Citation: Smirnov R.Yu., Pande S., Kolenchukova O.A., Kratasyuk V.A. Household management of pesticides and chemical contaminants in fruit and vegetables. J. Sib. Fed. Univ. Biol., 2017, 10(2), 179-186. DOI: 10.17516/1997-1389-0021.

(c) Siberian Federal University. All rights reserved

* Corresponding author E-mail address: rostislav.smirnov.93@mail.ru 


\title{
Бытовой контроль химических загрязняющих веществ и пестицидов во фруктах и овощах
}

\author{
Р.Ю. Смирнов ${ }^{\text {a }}$ Шубра Панде \\ О.А. Коленчукова ${ }^{\text {a, }}$, В.А. Кратасюк ${ }^{\text {a,в }}$ \\ ${ }^{a}$ Сибирский федеральный университет \\ Россия, 660041, Красноярск, пр. Свободньій, 79 \\ ${ }^{6}$ Научно-исследовательский институт \\ медицинских проблем Севера \\ Россия, 660022, Красноярск, ул. Партизана Железняка, 3 Г \\ ${ }^{8}$ Институт биофизики СО РАН \\ Федеральный исследовательский иентр \\ «Красноярский научный изентр СО РАН» \\ Россия, 660036, Красноярск, Академгородок, 50/50
}

Беспорядочное применение пестициидов, искусственных гормонов роста, пищевого воска и красителей приводит к тому, что население неосознанно потребляет их вместе с овощами и фруктами. Пестищуиды характеризуются исключительной мобильностью и биостойкостью, что позволяет им распространяться далеко за предель обрабатьваемых площчадей и загрязнять целье экосистемы. На основании многочисленных исследований доказана потенцииальная опасность пестиццидов для здоровья человека, и поэтому они запрещены 8 некоторых странах. Искусственные стимуляторы роста провоцируют раковые заболевания, наносят ущерб гормональной системе человека, вызывают аллергчческие реакции. Пищевой воск, используемый для придания привлекательного вида продукции с ичелью максимизации прибыли, не менее токсичен. Тщุательный выбор продуктов питания и применение простейших методов их обработки могут свести к минимуму вредное воздействие этих веществ на здоровье человека.

Ключевые слова: пестицииды, гормоны роста, продукты питания, загрязнения.

\section{Introduction}

Fruit and vegetables are rich providers of several nutrients and bioactives which serve as the potent nutraceuticals (Pande et al., 2012; Pande et al., 2013) and all the leading health organizations, doctors, and nutritionists promote their liberal consumption so as to ensure good health and prevent/cure diseases. Cultivation of the fruit and vegetables involves heavy usage of pesticides that include insecticides, fungicides, rodenticides, bactericides, and larvecides to minimize spoilage and maximize the quantity of harvest. Fenik et al. (2011) reported two main classes of pesticides viz. inorganic and organic. Inorganic class includes pesticides with arsenic, fluorine, etc., while organic class comprises of organochlorine, organophosphorus, and organonitrogen pesticides.

These pesticides are highly poisonous, which acts through different routes such as contact poisoning via skin, respiration or ingestion to bring about death of the targeted pest (Singh et al., 2007). Pesticides through environment (food chain and other sources) 
reach and affect the non-targeted organisms (humans and animals).

The metabolites and breakdown products of pesticides remain active in the environment and contaminate the biosphere. Food, water, soil, rivers, underground water table, and even breast milk; the pesticides are found everywhere. Further, photolytic degradation, evaporation to atmosphere, leaching to water table, contamination to the river or nearby waterbodies followed by condensation to form clouds, absorption into the edible plant parts are possible vehicles that disseminate pesticides to reach the population residing thousand kilometers away from area of its active application. Some variants of the pesticides are extremely stable and are carried forward to the next generations also. Thus, the impact of pesticide application sustains for long due to its active mobility and bioaccumulation.

Human beings are reservoir of pesticides and they enter our body through oral (food and water), dermal, and respiratory path, of which oral route remains the most common. Wide variety of fruit and vegetables such as lettuce, spinach, peppers, tomatoes, celery, potatoes, carrots, cucumbers, green beans, cauliflower, tomatoes, sweet potatoes, eggplants, broccoli, peas, bananas, cherries, oranges, grapes, and mushrooms have been found to be heavily contaminated with organophosphorus, carbamates, and organonitrogen pesticides. Both organophosphorus and organonitrogen pesticides operate by inhibiting the activity of acetylcholinesterase in the nervous system, and, as a result, acetylcholine levels increase causing hyperarousal, muscle paralysis, and blockage of respiratory center leading to increased heart rate, palpitation, muscle twitching in the humans after prolonged exposure (Papadakis et al., 2006; Jokanovic, 2009). After reaching the human digestive system, these pesticides can be potent carcinogenic agents and cause several cancers (Chen et al., 2007). Organochlorine pesticides are neurotoxic and cause alteration in ion channels and affect carbohydrate metabolism in humans (Garg et al., 2004). Reports suggest that pesticides can also affect normal thyroxine levels (Miranda-Contreras et al., 2013) thereby affecting reproductive abilities in humans. Further, their adverse effect can also be seen on the adenosine triphosphate (ATP) levels in human cerebrum and can cause confusion, hemorrhage, irritability, and insomnia (Van Maele-Fabry et al., 2013). Other harmful effect of the pesticides on humans include paralysis, respiratory and gastrointestinal tract disturbances, mutations, allergies, etc. (Fenik et al., 2011; Keikotlhaile et al., 2011), while other reports suggest that prolonged exposure to pesticides may harm neurons leading to increased susceptibility towards Alzhimers disease in aged population (Rauh et al., 2006). Unfortunately, despite such deleterious effects, the usage of pesticides has only increased significantly over the years. Although numerous pesticides are banned in several countries, their persistence in the environment have impacted it drastically and, subsequently, our health as well!

For public health, the Government sets Maximum Residual Level (MRL) in accordance with WHO/FAO guidelines so as to determine acceptable limit of a pesticide in foods. However, pesticides break down into unknown but harmful residues that escape quarantine through standard detection methods and ultimately reach markets and household; eventually affecting the health of the population. Androutsopoulos et al. (2013) has elaborated the mutual interaction of several pesticides and resulting toxic impact on human health through process of potentiation, additive effect, synergism or antagonism with other active metabolites, ions, etc. These effects depend upon the chemical properties and modes of action of these pesticides. 
Apart from pesticides, there is a rampant use of chemicals like ethylene and calcium carbide to bring about the artificial ripening of fruit and vegetables. It is no surprise to see fruit and vegetables in the market out of season. Ethylene is relatively safe for human health but it is expensive. This had led to indiscriminate use of cheap and locally available calcium carbide for artificial ripening. The carcinogenic potential of calcium carbide is well documented and its usage is banned in many countries. It is associated with several health implications such as vomiting, diarrhea, muscle weakness, neurological impairment, speech disruption, confusion, abortions, congenital anomalies, cerebral edema, etc. (Dhembare, 2013; Mursalat et al., 2013; Bouchard et al., 2011). Use of formalin to enhance shelf life of fruits and vegetables is evident and an irony that formalin which is used to preserve the dead is also used to preserve the edibles! Formalin causes myriad of respiratory tract disturbances and is potent carcinogen. Non edible materials as fruit dyes, fruit waxes, fruit shiners, non-permitted colors, mineral oils, and many other chemicals (even arsenic and phosphorus hydride) are used on fruits to impart deceptive appearance for commercial gains. Such chemical contaminants can cause violent allergic reactions, liver and respiratory disorders, cancers and neurological disorders (Rahim, 2012; Ensafi et al., 2014). It's a pathetic situation that food consumption (basic amenity for human life) also involves an opportunity to consume several inedible substances which are potential carcinogens and allergens. As we become aware about the presence and effects of pesticides and chemical contaminants in foods, is there anything we can do at individual level to minimize the levels of pesticides and chemical contaminants in our food plate?

There are several sophisticated methods such as GC-MS, LC-MS, HPLC, spectrophotometry, etc. to detect pesticide and hazardous heavy metals in the edible foods. Most of these methods require trained professionals and expensive laboratory set up to conduct scientific analysis and report results about pesticide residues in samples. But since the food market cannot deny the presence of pesticide residues in a wide range of foodstuffs, what should we do about it? On an individual and household basis, there are well investigated techniques to bring down the pesticides and chemical contaminants levels in the fruit and vegetables below the threshold limit for safe consumption. A simple awareness and regular practice can help us protect against them.

\section{Effective household treatments}

Food processing is a valuable additional strategy to make raw food more attractive, easily digestible, tasty, and safe for consumption (McClements, 2015). Several studies have indicated that the basic household food processing techniques such as washing, peeling, soaking, cooking, blanching, concentrating, etc. reduce the pesticide concentration by leaching it off (Bajwa et al., 2014; Keikotlhaile et al., 2011). Effect of the food processing on pesticide residue level is multifactorial and affected by the physicochemical properties of food such as solubility, volatility, thermal stability, etc. (Keikotlhaile et al., 2011), but there is a certain decrease in the pesticide concentration after food processing. However, the rate of reduction varies from food to food and from process to process.

Preliminary step in food processing is washing. Yuwei et al. (2009) observed that the concentration of malathion, carbaryl, dimethoate, and fenthion residues were significantly lowered in vegetables after judicious washing, while Tejada et al. (1990) reported the reduction of chlorpyriphos residues in food grains (rice and wheat) by this important step. Rate of rinsing off 
is not affected by its solubility in water (Cengiz et al., 2007); however addition of chlorine, hydrogen peroxide, acetic acid, etc. plays more effective role in the removal of pesticide residues during washing (Bajwa et al., 2014). Reports show that $1 \%$ salt solution best removes chlorothalonil from cabbage (Satpathy et al., 2011) while dipping vegetables in salt solution for 10 minutes followed by washing significantly removed pesticide residues from the okra (Nair et al., 2014) and tomatoes (Harinathareddy et al., 2014). Chlorinated and ozonized water also enhances the efficacy of removing pesticide residues from fruit and vegetables when used for 10 minutes (Ikeura et al., 2011). The length of washing cannot be overstretched as it may lead to loss of water soluble nutrients too. Other steps performed after washing are also documented to leach out pesticides and chemical contaminants.

Peeling off dislodges the pesticide residues in the fruit and vegetables (70-100\%) as the skin holds more pesticide residues than the inner pulp (Cengiz et al., 2007). The food processing includes cooking as a major component. Cooking has been documented to reduce the aged pesticide residues in the foods (Chavarri et al., 2005). Kaushik et al. (2016) reported the significant lowering of deltamethrin residues in chick pea after subjecting to cooking. Other moist thermal cooking treatments (steaming, blanching, and pasteurization) also contributes to significant pesticide content decrease (Keikotlhaile et al., 2011; Bajwa et al., 2014). Thus, we understand that the simple and basic household treatments may aid us in removal of pesticides and chemical contaminants but at the same time careful selection of edibles is important.

One must begin with emphasis on the safe selection of foods using the visual stimulus. If the branch of the fruit is green but the fruit are unusually bright yellow, it indicates forceful ripening. Also if the whole bunch of fruit has a uniform color with less or no spots or marks, there are high chances that the fruit is artificially ripened. Such bunch of fruit should be discouraged from purchasing. The natural cluster/bunch of fruit or vegetables are never alike, there are considerable variations and appearance of spots, cracks, marks denote a naturally ripened fruit. Careful selection of naturally ripened fruit with black or brown marks, uneven color in the bunch ensures selection of good fruit. The natural shape and size of the vegetable can be an important clue and an unusually bloated shape with marked sheen on the surface shows significant application of the chemical treatment. Discourage the purchase and consumption of off-season fruit and vegetables. Such fruit and vegetables are ripened by hormones, colored by dyes so as to gain appropriate shape and size much before/ after the season. Seasonal fruit are always better choice and are cheaper too as their production is not mediated by man-made conditions. After careful selection, the food processing methods can accelerate the removal of chemical contaminants, favoring consumption of fruit and vegetables in their most natural form. Beside this, one cannot ignore benefits of practicing organic farming, preferably growing your own fruit and vegetables under careful supervision. This method promotes healthy eating with involvement in the food grown thereby minimizing wastage.

Many approaches have been designed to detect the pesticide and chemical contaminants in fruit and vegetables using GC-MS, LC-MS, spectrophotometry, flurometry, etc. These methods can be performed in laboratory by installing sophisticated equipments and skilled technicians. At a basic household level, usage and utility of these techniques do not hold good. Studies have revealed bioluminescence based detection of pesticides 
as rapid, cost-effective, and extremely simple. This method holds tremendous capacity to detect pesticides, heavy metals, and chemical contaminants at very small level (Ranjan et al., 2012; Esimbekova et al., 2014; Kratasyuk et al., 2015). We await development of such sensitive tools to detect harmful contaminants in the food to minimize their hazardous effects at household level. Until then, awareness and caution at individual level in the household can safeguard one against harmful effects of chemical contaminants in fruit and vegetables to a considerable extent.

\section{Acknowledgements}

The research was partially supported by Government of Krasnoyarsk Territory, Krasnoyarsk Region Science and Technology Support Fund to the research project and Russian Foundation for Basic Research [project No 16-44242126] and Post-Doctoral Program of Russian Academic Project “5-100” [Grant № M 2.2.3].

\section{References}

Androutsopoulos V.P., Hernandez A.F., Liesivuori J., Tsatsakis A.M. (2013) A mechanistic overview of health associated effects of low levels of organochlorine and organophosphorous pesticides. Toxicology, 307: 89-94

Bajwa U., Sandhu K.S. (2014) Effect of handling and processing on pesticide residues in food a review. Journal of Food Science and Technology, 51(2): 201-220

Bouchard M.F., Chevrier J., Harley K.G., Kogut K., Vedar M., Calderon N., Trujillo C., Johnson C., Bradman A., Barr D.B., Eskenazi B. (2011) Prenatal exposure to organophosphate pesticides and IQ in 7-year-old children. Environmental Health Perspectives, 119(8): 1189-1195

Cengiz M.F., Certel M., Karakaş B., Göçmen H. (2007) Residue contents of captan and procymidone applied on tomatoes grown in greenhouses and their reduction by duration of a pre-harvest interval and post-harvest culinary applications. Food Chemistry, 100(4): 1611-1619

Chavarri M.J., Herrera A., Arino A. (2005) The decrease in pesticides in fruit and vegetables during commercial processing. International Journal of Food Science \& Technology, 40(2): 205-211

Chen S., Sun D., Chung J.S. (2007) Treatment of pesticide wastewater by moving-bed biofilm reactor combined with Fenton-coagulation pretreatment. Journal of Hazardous Materials, 144(1): $577-584$

Dhembare A.J. (2013) Bitter truth about fruit with reference to artificial ripener. Archives of Applied Science Research, 5(5): 45-54

Ensafi A.A., Jamei H.R., Heydari-Bafrooei E., Rezaei B. (2014) Development of a voltammetric procedure based on DNA interaction for sensitive monitoring of chrysoidine, a banned dye, in foods and textile effluents. Sensors and Actuators B: Chemical, 202: 224-231

Esimbekova E., Kratasyuk V., Shimomura O. (2014) Application of enzyme bioluminescence in ecology. Advances in Biochemical Engineering / Biotechnology, 144: 67-109

Fenik J., Tankiewicz M., Biziuk M. (2011) Properties and determination of pesticides in fruits and vegetables. TrAC Trends in Analytical Chemistry, 30(6): 814-826

Garg U.K., Pal A.K., Jha G.J., Jadhao S.B. (2004) Haemato-biochemical and immunopathophysiological effects of chronic toxicity with synthetic pyrethroid, organophosphate and chlorinated pesticides in broiler chicks. International Immunopharmacology, 4(13): 1709-1722 
Harinathareddy A., Prasad N.B.L., Devi K.L. (2014) Effect of household processing methods on the removal of pesticide residues in tomato vegetable. Journal of Environmental Research and Development, 9(1): 50-57

Ikeura H., Kobayashi F., Tamaki M. (2011) Removal of residual pesticides in vegetables using ozone microbubbles. Journal of Hazardous Materials, 186(1): 956-959

Jokanović M. (2009) Medical treatment of acute poisoning with organophosphorus and carbamate pesticides. Toxicology Letters, 190(2): 107-115

Kaushik G., Satya S., Naik S.N. (2016) Pesticide residue dissipation upon storage and processing in chickpea legume for food safety. Advances in Food Technology and Nutritional Sciences, 2(2): 64-72

Keikotlhaile B.M., Spanoghe P. (2011) Pesticide residues in fruits and vegetables. Pesticides formulations, effects, fate. Stoytcheva M. (ed.) InTech, p. 243-252

Kratasyuk V.A., Esimbekova E.N. (2015) Applications of luminous bacteria enzymes in toxicology. Combinatorial Chemistry \& High Throughput Screening, 18(10): 952-959

McClements D.J. (2015) Food emulsions: principles, practices, and techniques. CRC Press, $280 \mathrm{p}$.

Miranda-Contreras L., Gómez-Pérez R., Rojas G., Cruz I., Berrueta L., Salmen S., Morales Y. (2013) Occupational exposure to organophosphate and carbamate pesticides affects sperm chromatin integrity and reproductive hormone levels among Venezuelan farm workers. Journal of Occupational Health, 55(3): 195-203

Mursalat M., Rony A.H., Rahman A.H.M.S., Islam M.N., Khan M.S. (2013) A critical analysis of artificial fruit ripening: scientific, legislative and socio-economic aspects. ChE Thoughts, 3(1): 1-7

Nair K.P., Mathew T.B., Beevi S.N., George T. (2014) Monitoring and decontamination of pesticide residues in okra (Abelmoschus esculentus Moench). International Journal of Interdisciplinary and Multidisciplinary Studies, 1(5): 242-248

Pande S., Srinivasan K. (2012) Potentiation of hypolipidemic and weight-reducing influence of dietary tender cluster bean (Cyamopsis tetragonoloba) when combined with capsaicin in high-fat-fed rats. Journal of Agricultural and Food Chemistry, 60(33): 8155-8162

Pande S., Srinivasan K. (2013) Protective effect of dietary tender cluster beans (Cyamopsis tetragonoloba) in the gastrointestinal tract of experimental rats. Applied Physiology, Nutrition, and Metabolism, 38(2): 169-176

Papadakis E.N., Vryzas Z., Papadopoulou-Mourkidou E. (2006) Rapid method for the determination of 16 organochlorine pesticides in sesame seeds by microwave-assisted extraction and analysis of extracts by gas chromatography-mass spectrometry. Journal of Chromatography A, 1127(1): 6-11

Rahim M.A. (2012) Indiscriminate use of chemical in fruits and their health effects. Proceedings of First AFSSA Conference on Food Safety and Food Security held at Osaka Prefecture University, Osaka, Japan. p. 17-25

Ranjan R., Rastogi N.K., Thakur M.S. (2012) Development of immobilized biophotonic beads consisting of Photobacterium leiognathi for the detection of heavy metals and pesticide. Journal of Hazardous Materials, 225: 114-123

Rauh V.A., Garfinkel R., Perera F.P., Andrews H.F., Hoepner L., Barr D.B., Whitehead R., Tang D., Whyatt R.W. (2006) Impact of prenatal chlorpyrifos exposure on neurodevelopment in the first 3 years of life among inner-city children. Pediatrics, 118(6): e1845-e1859 
Satpathy G., Tyagi Y.K., Gupta R.K. (2011) Removal of organophosphorus (OP) pesticide residues from vegetables using washing solutions and boiling. Journal of Agricultural Science, 4(2): 69-78

Singh D., Sharma R.R. (2007) Postharvest diseases of fruit and vegetables and their management. Sustainable pest management. Prasad D. (ed.) New Delhi, India, Daya Publishing House

Tejada A.W., Calumpang S.M.F., Gambalan N.B. (1990) Effect of processing on residues of chlorpyrifos in stored corn and rice. Philippine Agriculturist, 73(3-4): 375-385

Van Maele-Fabry G., Hoet P., Lison D. (2013) Parental occupational exposure to pesticides as risk factor for brain tumors in children and young adults: a systematic review and meta-analysis. Environment International, 56: 19-31

Yuwei Y., Zhihua Z.Z.Y. (2009) Effects of processing on pesticide residues in cabbage and its dietary exposure assessment. Journal of Chinese Institute of Food Science and Technology, 6: 046 